\title{
A Study on Estimation of Demolition Waste Generation Index by using CART (Classification and Regression Tree) Analysis
}

\author{
Gi. Wook. Cha, Won. Hwa. Hong, Kang. Guk. Lee \\ School of Architectural, Civil, Environmental and Energy Engineering \\ Kyungpook National University \\ Daegu City, South Korea \\ ckgnr@nate.com
}

\begin{abstract}
This study aims to predict demolition waste generation rate (DWGR) of the detached house by their types and materials when they are demolished. To achieve this objective, required data was collected based on material information of the buildings investigated before demolition. By using the established database in this research, CART analysis was conducted, with the buildings' types and materials as analysis factors, to identify what affects the generation of waste concrete and to estimate index of waste generation. The results were as follows. First, the most influential factor on the generation of waste concrete was types of buildings. Second, generation of waste concrete of RC-type and wood-type buildings was not affected by materials, while that of masonry-type buildings was affected by roof materials. Masonry-type buildings were divided into two categories by roof materials: i) buildings with slab and slab with roof tiles as roof materials and ii) buildings with roof tiles and slate as roof materials. Third, amounts of waste concrete of RC-type and wood-type buildings were $0.324 \mathrm{~m}^{3} / \mathrm{m}^{2}$ and $0.018 \mathrm{~m}^{3} / \mathrm{m}^{2}$, respectively, and those of masonry-type buildings with roof materials of slab and slab with roof tiles and the other masonry-type buildings were $0.127 \mathrm{~m}^{3} / \mathrm{m}^{2}$ and $0.040 \mathrm{~m}^{3} / \mathrm{m}^{2}$, respectively.
\end{abstract}

Keywords: C\&D waste; DWGR; Detached house; waste concrete; CART analysis

\section{INTRODUCTION}

The increase of construction and demolition (C\&D) waste causes serious environmental damage around the world. Therefore, appropriate control of C\&D waste and specifically useful tools for the control are required. Previous studies have pointed out indicators of the waste generation as a useful tool of C\&D waste management [1,2].

To identify indicators of the waste generation, most of the previous studies have focused on waste generated during construction [3]. However, the majority of C\&D waste is demolition waste [4]. In South Korea where construction activities start after demolishing existing buildings, the study on demolition waste is highly important.

It is demanding to predict demolition waste generation rate (DWGR) generated when a building is demolished. In particular, it is more challenging to estimate indicators of waste generated from the detached house with a wide range of building types and materials than multiple-unit buildings, office buildings, or factories with similar types and materials.

This research focused on residential buildings, aiming at estimating the indicators of DWGR so as to predict an amount of waste of detached house according to their types and materials.

\section{PREVIOUS RESEARCH IN DEMOLITION WASTE GENERATION INDEX IN KOREA}

Seoul Development Institute (SDI) [5] computed DWGR using indirect measurement, whereby material inputs (excluding material losses during construction) were considered the amounts of waste generated. The DWGR was defined for each of the three types of residential buildings/structures, namely brick houses, wooden houses, and RC (Reinforced Concrete) houses. Korea Environment \& Resources Corporation (KECO) [6] assessed DWGR based on international literature and material inputs and losses (ratios). They divided residential dwellings into tiled houses, masonry houses, wooden houses, and RC structures. In a study by the National Housing Corporation [7], detached houses were divided into western dwellings, Korean dwellings, and houses with slate roofing. For each of these, pre-research investigation was carried out on the buildings scheduled for demolition, and indirect measurement was used to calculate DWGRs. Direct measurement was employed by Kim [8] in estimating DWGR for three types of dwellings: wooden houses, brick houses, and $\mathrm{RC}$ houses. The Ministry of Environment of the Republic of Korea [9] conducted a study on Recycling Guidelines and Recycling Promotion of Construction Wastes. That study looked into previous data/information to indirectly measure DWGR. Residential dwellings were divided into detached houses, wooden houses, and apartments. DWGR was assessed for each of these types.

Presented above was a comprehensive review of the main ideas about the DWGRs that were reported in previous studies by Korean researchers, wherein emphasis was placed on assessment methodology. Problems found in the earlier studies on DWGR, and information to be complemented therein are summarized as follows: (a) Computing DWGR based on either previous research literature or on studies by international 
researchers may not fully represent the reality in Korea; (b) When assessing DWGR using material inputs and losses (ratios), changes in material inputs do not always get accurately incorporated into the actual inputs, as buildings themselves would sometimes undergo remodeling and/or repair; (c) Studies using direct measurement are few in number and report only the total amount of waste generated, thus making it difficult to estimate the amount generated for each waste type; and (d) no clearly-defined housing classification system is available. It is considered the first thing to do on classification of buildings is to establish clear guidelines based on types of structures or materials (key members) of buildings.

TABLE I. THE DEFINITION AND CLASSIFICATION OF DETACHED HOUSE

\begin{tabular}{|c|c|c|}
\hline Reference & $\begin{array}{l}\text { Type of } \\
\text { house }\end{array}$ & Definition \\
\hline \multirow{4}{*}{$\begin{array}{l}\text { Enforcement } \\
\text { Decree of } \\
\text { the Building } \\
\text { Act }\end{array}$} & $\begin{array}{l}\text { Detached } \\
\text { house }\end{array}$ & $\begin{array}{l}\text { Free-standing residential buildings including } \\
\text { home childcare facilities, local childcare } \\
\text { centers, neighborhood living facilities, and } \\
\text { welfare facilities for senior citizens }\end{array}$ \\
\hline & $\begin{array}{l}\text { Multi- } \\
\text { unit } \\
\text { detached } \\
\text { house }\end{array}$ & $\begin{array}{l}\text { Residential buildings meeting all of the } \\
\text { following requirements. } \\
\text { (1) Designed for a number of people like } \\
\text { students or office workers to live in a long } \\
\text { period of time } \\
\text { (2) Not independent residence } \\
\text { (3) Gross floor area shall be } 330 \mathrm{~m}^{2} \text { or less, } \\
\text { and the number of floors shall be } 3 \text { or less }\end{array}$ \\
\hline & $\begin{array}{l}\text { Multi- } \\
\text { family } \\
\text { detached } \\
\text { house }\end{array}$ & $\begin{array}{l}\text { Residential buildings meeting all of the } \\
\text { following requirements but not falling under } \\
\text { multi-unit dwelling } \\
\text { (1) The number of floors that is used as a } \\
\text { house shall be } 3 \text { or less (excluding basement). } \\
\text { However, if the first floor is used as parking } \\
\text { space with Piloti, it shall be excluded. } \\
\text { (2) In a single building, the total floor area } \\
\text { used as a house (excluding basement parking } \\
\text { space) shall be } 660 \mathrm{~m}^{2} \text { or less. } \\
\text { (3) Up to } 19 \text { families shall be accommodated. }\end{array}$ \\
\hline & $\begin{array}{l}\text { Official } \\
\text { residence }\end{array}$ & - \\
\hline $\begin{array}{l}\text { Korean } \\
\text { social } \\
\text { indicators }\end{array}$ & $\begin{array}{l}\text { Detached } \\
\text { house }\end{array}$ & $\begin{array}{l}\text { Free-standing residential buildings including } \\
\text { single-family detached houses and multi- } \\
\text { family detached houses. }\end{array}$ \\
\hline
\end{tabular}

\section{METHODOLOGY}

\section{A. The definition of detached house}

In accordance with Article 3-4 of Enforcement Decree of the Building Act in Korea, residential buildings are roughly classified into detached houses and multi-unit houses. And the detached house, which was studied in this research, is classified in detail into separate houses, multi-unit detached houses, multi-family detached houses, and official residences. However, the definition of the detached house made by social indicators is different from that made by the Building Act. According to social indicators, the detached house refers to single-family detached house and multi-family detached house. Table I shows the two different classifications for the detached house.

In a local or national government driven statistics survey, residential buildings are divided into detached houses, multi- unit houses, and houses in non-residential buildings. In detail, the detached house is classified into separate houses, multifamily detached houses, and others, while the multi-unit house is divided into apartment buildings, multi-family residences, and row houses [10].

\section{B. Scope of this stidy}

The main objective of this research is to calculate an amount of waste concrete, which is generated the most during demolition, for the detached house. To achieve the objective, this research used the existing data established for the Ministry of Land, Transport and Maritime Affairs' project titled "Development of Advanced Demolition Technology for Environmentally Friendly Urban Restoration" executed in 2006-2011.

Table I lists the research items and relevant details for data collection and Fig. 1 shows the researched locations.

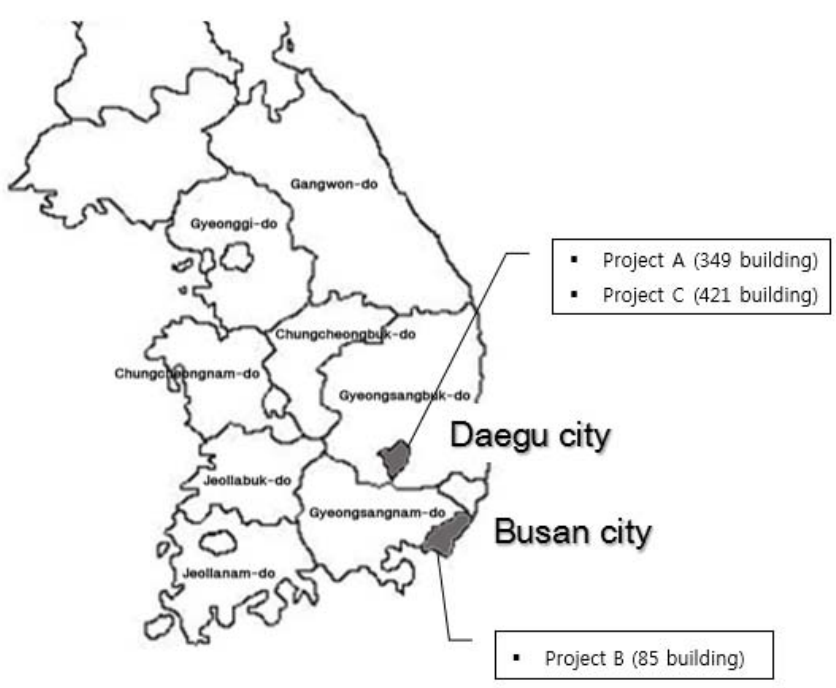

Fig. 1. The number of buildings and the location of target area

\section{Colletcing data}

Table II shows building information on each projects area. Unit of concrete quantity is $\mathrm{m}^{3} / \mathrm{m}^{2}$ (waste generated/gross floor area). And the DWGR is as the following formula:

$$
\text { DWGR }\left(\mathrm{m}^{3} / \mathrm{m}^{2}\right)=\text { DWG/GFA }
$$

TABLE II. THE CONTENTS OF INVESTIGATION OF BUILDINGS AND INTERNAL MATERIAL FOR COLLECTING DATA

\begin{tabular}{|l|l|}
\hline $\begin{array}{c}\text { Investigating } \\
\text { item }\end{array}$ & \multicolumn{1}{c|}{ Contents of investigation } \\
\hline Building & $\begin{array}{l}\text { Structure type (RC, masonry, and wood), structural } \\
\text { material (wall and roof); gross floor area }\end{array}$ \\
\hline Roof & Material, height, square measure, thickness, shape \\
\hline Wall & Material, height, length, square measure, thickness \\
\hline Pillar & $\begin{array}{l}\text { Pillar and which is not, material, height, specification of } \\
\text { pillar }\end{array}$ \\
\hline Floor & Material, square measure, thickness \\
\hline Stairs & Material, length \\
\hline
\end{tabular}


TABLE III. THE SUMMARY OF THE PROFILES IN PROJECT SITE UNDER STUDY

\begin{tabular}{|c|c|}
\hline Project A & $\begin{array}{l}\text { Demolition work was conducted in } 2007 \text {. The total number } \\
\text { of buildings was } 349 \text { and a total of the gross area was } \\
32,114 \mathrm{~m}^{2} \text {. Data on materials was collected through direct } \\
\text { investigation into the buildings from January to April in } \\
\text { 2007. The gross floor areas of RC type, masonry type, and } \\
\text { wood type structures were } 3,829 \mathrm{~m}^{2}, 20,423 \mathrm{~m}^{2} \text {, and } 6,862 \\
\mathrm{~m}^{2} \text {, respectively. }\end{array}$ \\
\hline Project B & $\begin{array}{l}\text { Demolition work was conducted in } 2007 \text {. The total number } \\
\text { of buildings was } 85 \text { and a total of the gross area was } \\
14,096 \mathrm{~m}^{2} \text {. Quantities of the materials were surveyed } \\
\text { through direct investigation into the buildings from March } \\
\text { to April in } 2007 \text {. The gross floor areas of RC type, } \\
\text { masonry type were } 10,132 \mathrm{~m}^{2} \text { and } 3,964 \mathrm{~m}^{2} \text {, respectively. }\end{array}$ \\
\hline Project C & $\begin{array}{l}\text { Demolition work was conducted in } 2007 \text {. The total number } \\
\text { of buildings was } 420 \text { and a total of the gross area was } \\
59,565 \mathrm{~m}^{2} \text {. Quantities of the materials were surveyed } \\
\text { through direct investigation into the buildings from July to } \\
\text { September in } 2007 \text {. The gross floor areas of RC type, } \\
\text { masonry type, and wood type structures were } 26,814 \mathrm{~m}^{2} \text {, } \\
26,150 \mathrm{~m}^{2} \text {, and } 6,600 \mathrm{~m}^{2} \text {, respectively. }\end{array}$ \\
\hline
\end{tabular}

\section{CART analysis}

As data used in this research was based on actual measurements, a data reliability issue could be raised. Therefore, pre-processing of the data collected was conducted to ensure its reliability before CART analysis. The preprocessing work included data cleaning by checking and eliminating outliers from the data. To identify the outliers, IQR (interquartile range) was applied, and relevant formula is as follows:

$$
\mathrm{Q} 1-1.5 \times \mathrm{IQR}<\text { selection of raw data }<\mathrm{Q} 3+1.5 \times \mathrm{IQR}
$$

where, Q3 is the value of $75 \%$ of the data while Q1 is the value of $25 \%$ of the data (IQR=Q3-Q1) [11].

Pre-processing work was conducted for data on 854 buildings acquired by the direct investigation, and (2) verified that 461 data out of the entire data were outliers, so they were eliminated. Since outliers for not only concrete but other construction materials were eliminated, the number of the raw data decreased considerably. Finally, data was reduced to 148 for project area A, 48 for project area B, and 197 for project area $\mathrm{C}$, and based on the data, CART analysis was conducted to obtain waste concrete generation. For the CART analysis, independent variables were type and materials of buildings while dependent variables were amounts of waste concrete generated.

In this research, CART analysis was conducted by using IBM SPSS 22.0 version software packages. Types (RC, masonry, and wood) and materials (materials of walls and roofs) of detached house were classified as shown in Table III.
TABLE IV. THE CLASSIFICATION OF STRUCTURE TYPE AND STRUCTURAL MATERIAL

\begin{tabular}{|l|l|l|l|}
\hline \multicolumn{2}{|c|}{ Classification } & \multicolumn{2}{|c|}{ Structural material } \\
\cline { 2 - 4 } & RC & \multicolumn{1}{|c|}{ Wall } & \multicolumn{1}{c|}{ Roof } \\
\hline \multirow{4}{*}{$\begin{array}{l}\text { Structure } \\
\text { type }\end{array}$} & Masonry & block, brick & $\begin{array}{l}\text { Slab, slab with roof } \\
\text { tiles, roof tiles, slate }\end{array}$ \\
\cline { 2 - 4 } & Wood & $\begin{array}{l}\text { block, brick, mud- } \\
\text { plastered wall }\end{array}$ & Roof tilse, slate \\
\cline { 2 - 4 } & \multicolumn{2}{|}{} \\
\hline
\end{tabular}

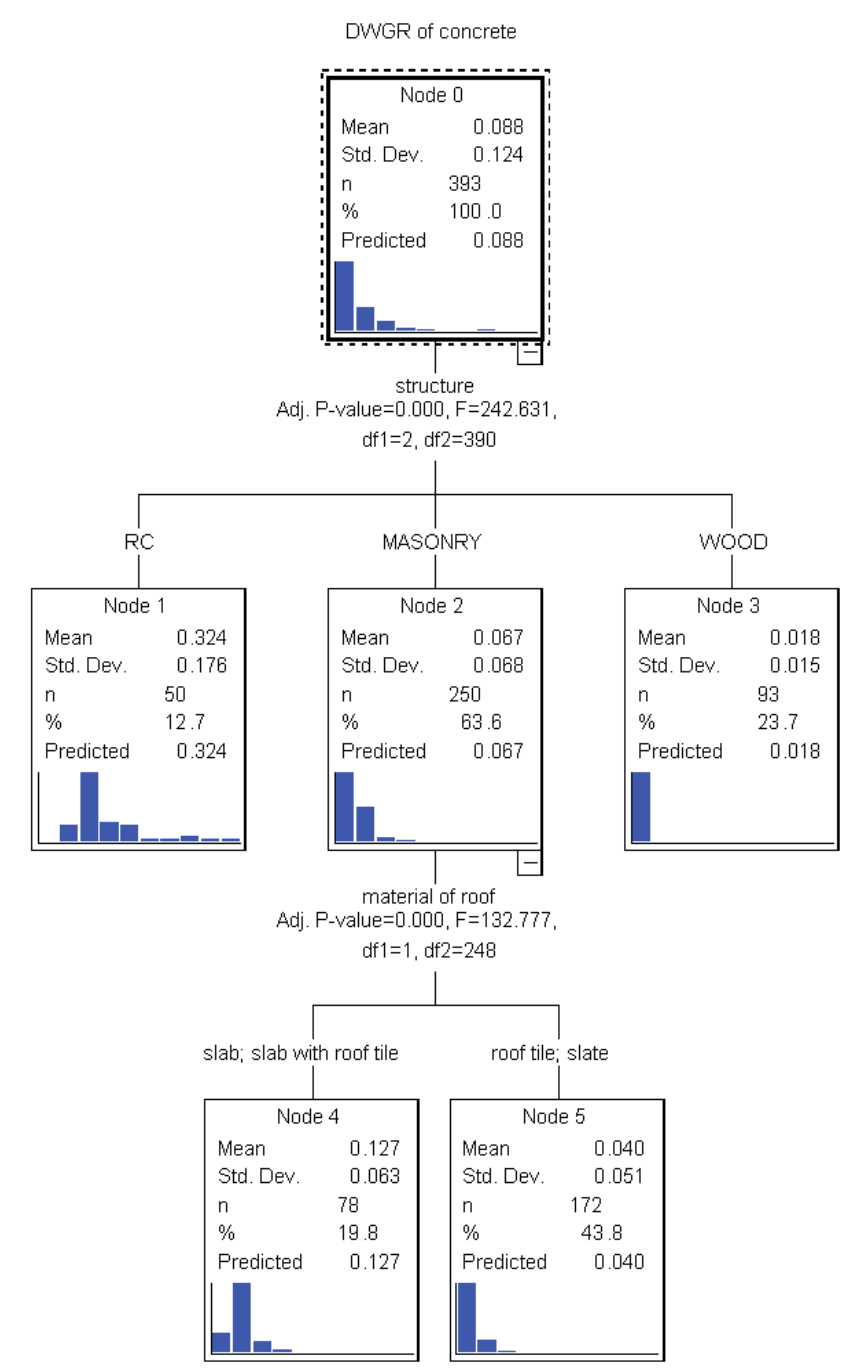

Fig. 2. The result of waste concrete generation by CART analysis

\section{RESUlTS AND DisCUSSION}

Fig. 2 illustrates the results of CART analysis on waste concrete generation based on types and materials of 393 detached house. The analysis revealed that generation of waste concrete was most greatly affected by types of buildings. As shown in Fig. 2, the mean value of waste concrete acquired from the entire data (in Node 0) was predicted to be 0.088 $\mathrm{m}^{3} / \mathrm{m}^{2}$. Depending on types of the buildings, the mean values of waste concrete generated from RC-type (Node 1), masonrytype (Node 2), and wood-type (Node 3) structures were 0.324 
$\mathrm{m}^{3} / \mathrm{m}^{2}, 0.067 \mathrm{~m}^{3} / \mathrm{m}^{2}$, and $0.018 \mathrm{~m}^{3} / \mathrm{m}^{2}$. Unlike other types, the masonry type buildings were divided into two: buildings with slab and slab with roof tiles as roof materials (Node 4) and buildings with roof tiles and slate as roof materials (Node 5). The mean value of waste concrete generated from the former was $0.127 \mathrm{~m}^{3} / \mathrm{m}^{2}$, while that from the latter was $0.040 \mathrm{~m}^{3} / \mathrm{m}^{2}$.

The CART analysis revealed that waste concrete generation of the RC-type and wood-type structures was not affected by wall and roof materials. It is deemed to be because wall materials of RC-type structures are blocks and bricks, which do not cause the generation of waste concrete, while roof materials of this type of structures are all slab, which does not make significant difference of waste concrete generation.

As for the wood-type structures, their wall materials include blocks, bricks, and mud-plastered wall, and the roof materials are roof tiles and slate. These materials do not seem to affect generation of waste concrete. For the above reasons, RC-type and wood-type buildings are expected not to have more Nodes as shown in Fig. 2.

However, two new nodes were created from the masonrytype buildings. Wall materials of this type of buildings are blocks and bricks, which do not cause the generation of waste concrete. But the roof materials are divided into two: i) slab and slab with roof tiles, and ii) roof tiles and slate. The former is deemed to cause generation of waste concrete, while the latter is not.

\section{CONCLUSION}

This research aims to identify demolition waste generated from the detached house with various types and materials. To achieve this objective, required data was collected based on material information of the buildings before demolition. To ensure the reliability of the collected data, pre-processing work was conducted before CART analysis. The analysis results were as follows.

The most influential factor on waste concrete generation was types of buildings. Amounts of waste concrete of RC-type and wood-type buildings were $0.324 \mathrm{~m}^{3} / \mathrm{m}^{2}$ and $0.018 \mathrm{~m}^{3} / \mathrm{m}^{2}$, respectively. But the generation of waste concrete of RC-type and wood-type buildings was not affected by materials.

Unlike other types, masonry-type buildings were divided into two sub categories by roof materials: i) buildings with slab and slab with roof tiles as roof materials and ii) buildings with roof tiles and slate as roof materials. And the waste concrete generation of the former was $0.127 \mathrm{~m}^{3} / \mathrm{m}^{2}$, and the latter, 0.040 $\mathrm{m}^{3} / \mathrm{m}^{2}$.

Through this research, we were able to estimate indicators of the waste concrete generation of buildings with various types and materials, as well as to identify factors affecting the generation of waste concrete. Also, the results of this research are deemed to allow us to categorize various types of structures into a number of groups based on their type and materials and to predict amounts of waste generated from the demolition of buildings. Still, further expanded research on this subject is required to estimate more various indicators of the $C \& D$ waste generation.

\section{ACKNOWLEDGMENT}

This work was supported by the National Research Foundation of Korea (NRF) grant funded by the Korea government (MSIP) (NRF-2014R1A1A2056152)

This research is modification and supplementation to doctorate thesis "A Study on the Prediction of $\mathrm{CO}_{2}$ Emissions and Cost in End-Life of Residential Building."

\section{REFERENCES}

[1] W.S. Lu, H.P. Yuan, J.R. Li, J.J. Hao, X.M. Mi, and Z.K. Ding, “An empirical investigation of construction and demolition waste generation rates in Shenzhen city," South China, Waste Manage, vol. 31, no. 4, pp. 680-687, 2011.

[2] H.P. Yuan and L.Y. Shen, "Trend of the research on construction and demolition waste management," Waste Manage, vol. 31, no. 4, pp. 670679, 2011.

[3] A.G. Bossink, and H.J.H. Brouwers, "Construction waste: quantification and source evaluation.” J. Constr. Eng. Manage. vol. 122, pp. 555-560, 1996.

[4] G.R. Mettam, and L.B. Adams, How to prepare an electronic version of your article, in: B.S. Jones, R.Z. Smith (Eds.), Introduction to the Electronic Age, E-Publishing Inc., New York, pp. 281-304, 1999.

[5] J.C. Chung, "Management Strategy for Construction and Demolition Waste and Their Recycling. Solid Waste Research Center in Development of Environmental Management," Seoul Development Institute, 1995

[6] Korea Environment \& Resources Corporation (KECO), "Recycling Guidelines and Recycling Promotion of Construction Wastes," Korea Environment \& Resources Corporation, 1995.

[7] S.K. Kim, "Disposal and Reuse of the Construction Wastes," Housing Research Institute in National Housing Corporation, 1997.

[8] G.J. Kim, “A Study on Eco-Friendly Construction Project Implementation and Strategy to Recycle Construction Debris and Waste," Construction Economy Research Institute of Korea (CERIK), 1997

[9] Ministry of Environment of Republic Korea, "A Study on Separate Collection and a Unit of Construction Waste," Ministry of Environment of Republic Korea, 2004

[10] Y.L. Kim, H.K. Yoon, J.Y. Kim, G.Y. Jeon, and W.H. Hong, "A Study on the energy Consumption and Greenhouse Gas Emission of the Detached Housein Daegu," J. Korean Housing Assoc. vol. 22, no. 2, pp. 35-42, 2011.

[11] S.J. Kang, and M. Lee, "Q-convergence with interquartile ranges," J. Econ. Dyn. Contr. vol. 29, no. 10, pp. 1785-1806, 2005.

[12] G.W. Cha, "A Study on the Prediction of $\mathrm{CO}_{2}$ Emissions and Cost in End-Life of Residential Building," Doctoral Dissertation, Kyungpook National University, 2014. 